\title{
GUIDING FUTURE RESEARCH ON THE VALORISATION OF SHREDDER FINE RESIDUES: A REVIEW OF FOUR DECADES OF RESEARCH
}

\author{
Tharaka Gunaratne *, Joakim Krook, Hans Andersson and Mats Eklund
}

Linköping University, Department of Management and Engineering, Division of Environmental Technology and Management, A building Campus Valla, Linkoping 581 83, Sweden

Article Info:

Received:

7 July 2019

Revised:

28 September 2019

Accepted:

24 October 2019

Available online:

20 November 2019

Keywords:

Shredder fines

Shredder residue

Valorisation

Recovery

Systems perspective

\begin{abstract}
Millions of tonnes of shredder fines are generated and disposed of globally, despite compelling reasons for its recovery. The absence of a review of previous literature, however, makes it difficult to understand the underlying reasons for this. Thus, this study attempts to investigate and assess what, to what extent, and in what ways shredder fines have been addressed in previous research. In doing so, guidelines are drawn for future research to facilitate the valorisation (upgrading and recovery) of shredder fines. Previous research concerning shredder fines was identified with respect to three main research topics. The material characterisation studies are predominantly confined to the occurrence of metals due to their recovery and contamination potential. The process development studies have often undertaken narrowly conceived objectives of addressing one resource opportunity or contamination problem at a time. Consequently, the full recovery (the retrieval of valuable resources and the bulk-utilisation as substitute material) potential of shredder fines has been largely overlooked. The main limitation of policy and regulation studies is the absence of in-depth knowledge on the implications of governmental waste- and resource-policies (macro-level) on actors' incentives and capacities (micro-level) for fines valorisation, which is necessary to understand the marketability of fines-derived resources. Undertaking a systems perspective is the key to recognising not only the different aspects within the individual research topics but also the inter-relations between them. It also facilitates the internalisation of the inter-relations into topical research.
\end{abstract}

\section{INTRODUCTION}

The shredding of end-of-life products has been gaining speed as an industrial activity worldwide, owing to the increasing consumption of goods. Waste streams such as end-of-life vehicles (ELVs) after depollution and dismantling, white goods, and industrial metallic scrap feed shredders around the world (Santini et al., 2012; Vermeulen et al., 2011). The entire process of shredding and post-shredder recovery of materials was developed primarily to recover metals.

A typical post-shredder recovery process starts by separating the shredded material into a light and a heavy fraction. What remains after recovering metals from these two fractions is known as the shredder residue. It consists of light fluff, heavy fluff, and a fine-grained material which is commonly identified as shredder fines or fines (Cossu and Lai, 2015; Vermeulen et al., 2011; Zorpas and Inglezakis, 2012). Globally, the annual generation of fines $(0-20 \mathrm{~mm})$ from the shredding of ELVs alone amounts to approximately four million tonnes, which is mostly shared between the regions of Europe and the US, while a relatively small proportion comes from Asia (Japan and Korea), as calculated from (Fiore et al., 2012), and (Vermeulen et al., 2011).

Even though advanced treatment processes are being employed to further recover materials (e.g. metals, plastics, and rubber) and energy (in incineration) from the larger fractions of shredder residues in certain countries, shredder fines continue to be disposed of throughout the world (Allen and Fisher, 2007; Santini et al., 2012; Singh and Lee, 2015a). Heterogeneity and small particle size are two prime factors that render the valorisation (upgrading and recovery ) of shredder fines technically challenging and economically unappealing (Fischer, 2006; Vermeulen et al., 2011). Meanwhile, in regions such as Europe, decreasing availability of landfill space, stringent legislation (e.g. the EU landfill directive) and policy demands for higher re-
* Corresponding author

Tharaka Gunaratne

email: tharaka.gunaratne@liu.se 
source efficiency (e.g. the EU end-of-life vehicles directive) have been gradually creating stronger incentives for the valorisation of shredder fines. Given that this fine-grained material $(0-20 \mathrm{~mm})$ could comprise as much as $70 \%$ of the shredder residue (Cossu et al., 2014), its valorisation is deemed as essential for the fulfilment of the ELV directive targets of $95 \%$ recovery and $85 \%$ recycling (European Commission, 2000).

Although shredder fines have been studied for decades, the research is still in an early phase of development. These studies have involved their own specific objectives, and targeted different types of fines and aspects of fines handling in varying parts the world (Edo et al., 2013; Gonzalez-Fernandez et al., 2008; Mallampati et al., 2018; Singh et al., 2016b; Singh and Lee, 2015b). Therefore, a coherent overview of the current knowledge levels regarding fines management is lacking, thus preventing common knowledge building and making it difficult to identify central areas for future research. Another feature of this body of research is that most studies have only addressed one specific aspect of fines management at a time (e.g. a specific material characteristic or a particular recovery process), thereby disregarding that changing current disposal practices and achieving valorisation is a multi-faceted challenge influenced by several inter-related technical, economic, organizational, market and policy aspects (Andersson et al., 2019; Iacovidou et al., 2017; van Beers et al., 2009).

This article aims to review and assess the contributions and limitations of previous studies on shredder fines in order to provide a coherent overview of current knowledge levels, and thereby, guide future research on its valorisation. In doing so, we first identify which topics of fines management have been studied, in what ways and to what extent, and then assess how these research approaches have influenced the breadth and depth of current knowledge. Beyond specific guidance of how the research could be further improved topic-wise, an emphasis is also put on the inter-relations between the different topics of fines management and how such a systemic approach could support the development of valorisation strategies. Knowledge gaps of relevance for the valorisation of fines in terms of topics or aspects not yet addressed by the research community are also discussed.

\subsection{Abbreviations}

- ELVs: End-of-life vehicles

- MSWI: Municipal solid waste incinerator

- FDRs: Fines-derived resources

\section{METHOD}

A three-step analytical approach was undertaken in this study (Figure 1). The initial part involved the search and selection of literature concerning shredder fines based on pre-determined procedures and criteria (Cronin et al., 2018). Subsequently, the selected articles were first divided into different research topics displaying the main aspects addressed. Within each topic, the literature was reviewed in regard to the objectives, methodological approaches, and main contributions of the studies (i.e. the type of generated results). Finally, guidelines for future research on shredder fines valorisation were derived via an assessment of the limitations in scope and applicability of the reviewed literature. The relevance of the inter-relations between research topics in facilitating fines valorisation, was also investigated in order to analyse the needs for employing a systems perspective in future research.

\subsection{Selection of literature}

The literature search was conducted using the bibliographic database Scopus and by considering all the available literature since 1975. Scopus is the largest database of peer-reviewed scientific literature, drawing from more than 5000 publishers (Scopus, 2018). Therefore, it was assumed that limiting the search to this database would still enable us to reach an adequate domain of scientific literature. In order to obtain all the literature encompassing shredder residues including shredder fines, the following sequence of search words was used for searching within the field "Article title, Abstract, Keywords" of the database:

\{shredder residue\} OR \{shredder residues\} OR \{shredder waste\} OR \{shredder wastes\} OR \{shredder fine\} OR \{shredder fines\}.

The reason for including both shredder residues and shredder fines in the search terms was the absence of a standard demarcation for shredder fines, as it is always identified for a particular shredding facility (Morselli et al., 2010).

The search resulted in 518 articles. The titles, abstracts, and keywords of these 518 articles were subsequently read in order to screen the articles that had a relevance to shredder fines. A maximum particle size of $20 \mathrm{~mm}$ was used in order to demarcate fines from other shredder residues, which is apparently the most appropriate according to current literature (Allen and Fisher, 2007; Edo et al., 2013; Izumikawa, 1999; Lanoir et al., 1997; Morselli et al., 2010; Reuter et al., 1999; Santini et al., 2012; Vermeulen et al., 2011). Literature that did not specifically address shredder fines (i.e. shredder residues of a particle size $<20 \mathrm{~mm}$ ) were disregarded, and 42 articles were initially selected for the review.

\subsection{Establishment of research topics and an over- view of their content}

The 42 selected studies were first reviewed mainly by reading through the title, abstract, and conclusions in order to identify which research topics they addressed. In total, this initial review led to the identification of three main topics, namely material characteristics, process development, and policy and regulation.

Fifteen articles were found concerning studies that have conducted different types of chemical and physical characterisations of the material. While some of these studies involve detailed characterisations of shredder fines specifically, others have characterised shredder residues as a whole and thereby only present limited information about the specific properties of the fine size fractions $(<20$ $\mathrm{mm}$ ). All these studies, however, were categorised under the topic of material characteristics. 


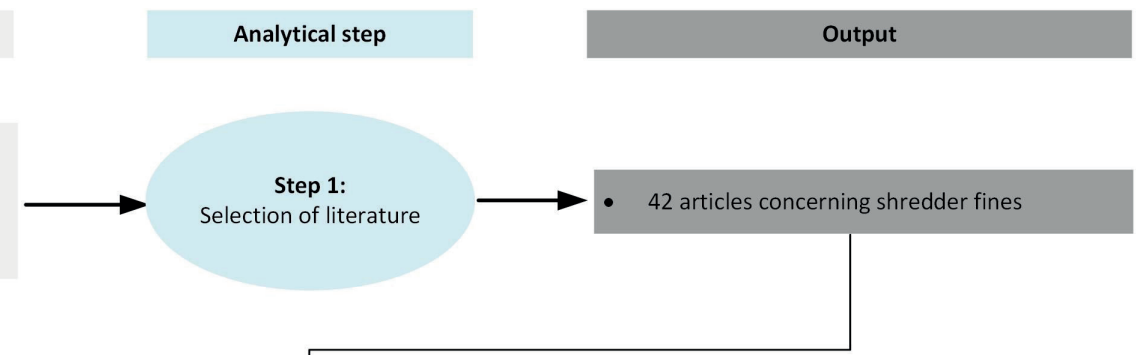

Establishment of

- What has been studied

- In what ways

- To what extent



- Assessment of scope and applicability of the topical literature

- Partly based on benchmarking against mature research on similar residues

Investigation of the inter-relations between the research topics

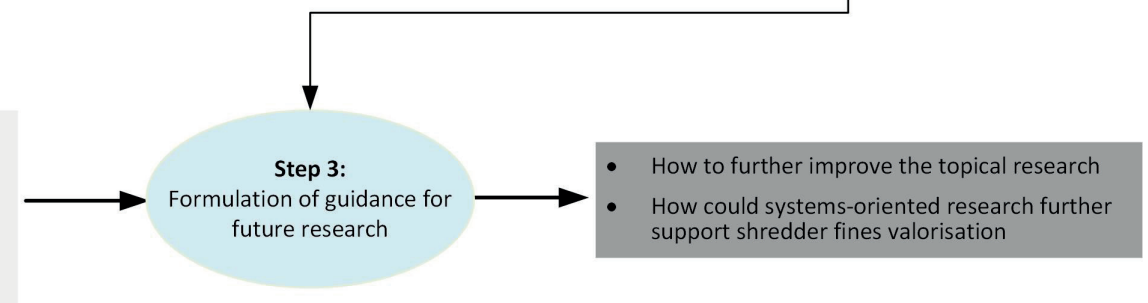

FIGURE 1: Illustration of the methodological approach of this paper.

Twenty-nine articles were found to focus on the development of technical processes for the treatment of shredder fines. Such studies investigate one or more of the following aspects: the recovery of specific materials from fines, the bulk utilisation of fines as a substitute material, and the reduction of the environmental risk of fines for disposal. This type of studies was categorised under the topic of process development. Unlike the studies in material characteristics, almost all of the literature in the process development category explicitly addresses shredder fines.

Four of the selected articles involved studies addressing the implications of governmental policy and regulation on the management and recovery of shredder fines in particular or shredder residues in general. The main reason for also including policy studies on the management of shredder residues (two studies) here was that such regulations could directly affect the conditions for the valorisation of shredder fines. These studies were categorised under the topic of policy and regulation.

It is worth noticing that some of the selected articles deal with more than one research topic. In such articles, a particular topic is always the primary focus while the others are secondary and thereby only partially addressed. For example, as part of process development (primary focus), material characterisation was performed (secondary). During the categorisation of the literature, such articles were included in both topics.

The studies within the identified research topics were then reviewed in detail to provide an overview of their different research objectives, methodological approaches, and main findings (i.e. the type of results generated). The intention behind such an overview was to facilitate the sub- sequent assessment of the scope and applicability of the main findings obtained within each of the research topics.

\subsection{Formulation of guidelines for future research}

As a means of formulating future research guidance, an emphasis was put on assessing how the scope and applicability of the provided results within each of the identified research topics could be further improved. This topic-wise assessment, however, was also complemented by a system perspective targeting the inter-relations between the research topics and how studying such inter-dependencies could further facilitate shredder fines valorisation.

\subsubsection{Assessment of scope and applicability of studies within the research topics}

The specific aspects of fines and their management studied under the research topics, are regarded as the scope. Thus, the assessment specifically targeted the research objectives and the breadth and depth of studied aspects within each research topic. This scope assessment was further supported by benchmarking the topical fines literature against more mature research on municipal solid waste incinerator (MSWI) bottom ash, displaying important aspects and knowledge levels for enabling the development of valorisation strategies. It is a comparable production residue to fines in terms of physical properties (e.g. heterogeneity and particle size) and chemical composition, and the fact that material characteristics can vary significantly depending on the input materials and incineration process. Review articles concerning MSWI bottom ash (Dou et al., 2017; Lam et al., 2010; Le et al., 2017; Margallo et al., 2015; Silva et al., 2017; Verbinnen et al., 2017) were 
primarily used as a means for conducting the benchmarking, while other literature was also used when necessary. Regarding the applicability of the reviewed topical literature, it was viewed here as the specific situations and settings under which the generated results are valid. Thus, this assessment involved a methodological review of how specific aspects of fines/fines management were studied within each research topic and in what way such procedures influence the applicability of the results.

The assessment of research in material characteristics was performed on the premise that the purpose of material characterisation would be the subsequent development of upgrading and recovery processes. There, for a heterogeneous material such as fines, a comprehensive knowledge of the chemical and physical properties is crucial (Allegrini et al., 2014; Fiore et al., 2012; Hernández Parrodi et al., 2018a). The scope was assessed in regard to the sufficiency of properties and the level of detail in characterisation. This was assisted by benchmarking against the MSWI bottom ash literature. The applicability was regarded as the undertaken sampling procedures and the material itself that was characterised (i.e. origin, quantity sampled, and particle sizes analysed). The applicability was assessed primarily concerning the ability of the sampling procedures to capture the variation of material composition, which contains crucial design parameters for the processes development (Allegrini et al., 2014; European Commission, 2004). The conditions due to materiality (i.e. origin, quantity sampled, and particle sizes analysed) were also considered.

The assessment of research in process development was performed based on the premise that the purpose of process development would be to recover valuable resources as well as avoid landfilling (by bulk utilisation as a substitute material). The scope was assessed regarding the sufficiency of the investigated aspects, i.e. the types of processes investigated, targeted resources and/or contaminants, and studied process attributes (e.g. pre-treatment, operating parameters, recovery efficiency, output characteristics, etc.) to enable full valorisation (i.e. the realisation of the full recovery potential) of shredder fines. Once again, this was assisted by benchmarking against MSWI bottom ash research. The applicability was assessed primarily in regard to the scale of operation for the developed processes, which is a direct indication of the technology readiness level (Mankins, 1995), and the material itself (i.e. origin and particle sizes) for which processes were developed.

The assessment of research in policy and regulation was performed based on the premise that the purpose of waste policy and regulation is to govern waste management, and such governance usually takes place at different socio-administrative levels (Hansen et al., 2002). The scope was assessed primarily based on the governing level on which knowledge was created, and the types of policyand regulation-implications investigated within these levels. Such assessment presumes that typical top-down-driven policy research would not create adequate knowledge on the actor level, where the valorisation actually takes place (Rocha et al., 2007; Sabatier, 2019). Benchmarking against MSWI bottom ash research was performed to as- sist in this assessment as well. The applicability was assessed based on the potential of the created knowledge to facilitate future policy interventions on the valorisation of shredder fines in relation to the geographical area (spatial boundaries) of study and the material itself (shredder residue or shredder fines) for which the policy and regulation was intended.

\subsubsection{Investigation of inter-relations between the research topics}

The importance of employing system-oriented research for facilitating the valorisation of industrial residues is commonly recognized in the literature (Andersson et al., 2019; lacovidou et al., 2017; Johansson et al., 2012). Here, such a perspective was used to investigate how the scope and applicability of shredder fines research could be further improved by also considering the inter-dependencies between the studied topics. Emphasis was primarily on providing guidelines on how the topical research on material characteristics, process development, and policy and regulation could be coordinated to better support the development of recovery strategies. This investigation also resulted in the identification of new, potentially important research topics that have not yet been studied for shredder fines, i.e. knowledge gaps.

\section{GENERAL OVERVIEW OF PREVIOUS RESE- ARCH CONCERNING SHREDDER FINES}

Except for a few early publications, shredder residues first started to receive noteworthy research attention in the 1990s (Figure 2). Since then, the interest in this topic has gradually increased. Although less than $10 \%$ of the research deals with shredder fines, the number of publications addressing the subject has also slowly increased during recent decades.

The research could be categorised according to three main research topics: material characteristics, process development, and policy and regulation. The research intensity is clearly prominent within the first two topics, which share 15 and 29 studies respectively, whereas only four studies are found within the policy and regulation topic (Figure 3).

In general, the pace of studies concerning shredder fines remained low globally until 2015, where a sudden increase in trend is visible. In addition, Europe accounted for more studies than the other regions. Only studies on process development could be seen as dispersed across different regions, whereas the studies on material characteristics were almost entirely limited to Europe. However, it is noteworthy that despite a sudden influx of process development research from Asia during recent years, eight of the articles from this region involve the same main author, plausibly as a consequence of mainstream research of this research group. Research in North America is only represented by four articles produced in the USA. The scarcity of research can perhaps be explained by the complex waste legislation, with more relaxed recovery objectives and availability of land for landfilling (Nayak and Apelian, 2014). 




FIGURE 2: Over-time research intensity on shredder residues and shredder fines $(<20 \mathrm{~mm})$ over the last four decades in terms of number of publications per year.

\section{ASSESSMENT OF SCOPE AND APPLICA- BILITY OF PREVIOUS RESEARCH}

In this section, the scope and applicability of previous research on shredder fines were assessed within the individual topics based on a review of the studies' research objectives, methodological approaches and main findings.

\subsection{Material characteristics}

Previous research on the material characteristics of shredder fines could be categorised in regard to two main objectives: the estimation of recovery potential and the estimation of environmental risks of disposal (Table 1). Although these objectives target different material characteristics of shredder fines, the studies within this topic have collectively established knowledge on several different types of chemical and physical properties. The characterised fines solely originate from Europe, and the research involves studies on various size fractions. In addition, the sampling procedures and type of characterised shredder fines vary significantly between the studies.

\subsubsection{Scope-related limitations}

One of the main scope-related issues of the research within this topic is that the established chemical and physical properties are scattered among the different studies. For instance, in studies targeting the recovery potential of fines, characterisation is done as part of developing a particular recovery process (Allen and Kolb, 2009; Konetschnik and Schneeberger, 2009; Péra et al., 2004; Reuter et al., 1999). Given the potential economic value of recovering base metals such as iron, copper, and zinc from fines, such metals have been a key focus in all of the studies. Consequently, only a few studies have established knowledge on the occurrence of other types of resources in fines such as plastics, minerals, other metals, and energy carriers. In the studies targeting environmental pollution risks (Börjeson et al., 2000; Fiore et al., 2012; Gonzalez-Fernandez et al., 2009, 2008; Lanoir et al., 1997), the characterisation focuses on base and heavy metals due to their high contamination potential and the metals-based regulation of landfill disposal in Europe. Only two studies have so far established knowledge on the presence of other contaminants in fines such as different types of organic compounds (Börjeson et al., 2000; Morselli et al., 2010). Given that the studies within this topic involve characterisation of selected chemical and physical properties for different types of fines (due to variations in input materials, shredding process, and particle size), a comprehensive understanding of both the resource and contamination potential is largely absent. As demonstrated by research on MSWI bottom ash (Dou et al., 2017; Lam et al., 2010; Margallo et al., 2015; Šyc et al., 2018), such comprehensive knowledge on the chemical and physical properties is essential for enabling effective development of resource recovery processes and facilitating the full valorisation of the material in question (Fiore et al., 2012; Hernández Parrodi et al., 2018a).

Another main scope-related issue in these studies is that the established chemical composition of fines typically limited to the total elemental concentrations. The sufficiency of such knowledge to spur subsequent process development is limited, as the form of occurrence of the different elements and materials influence both their recoverability and environmental pollution potential. For instance, MSWI 


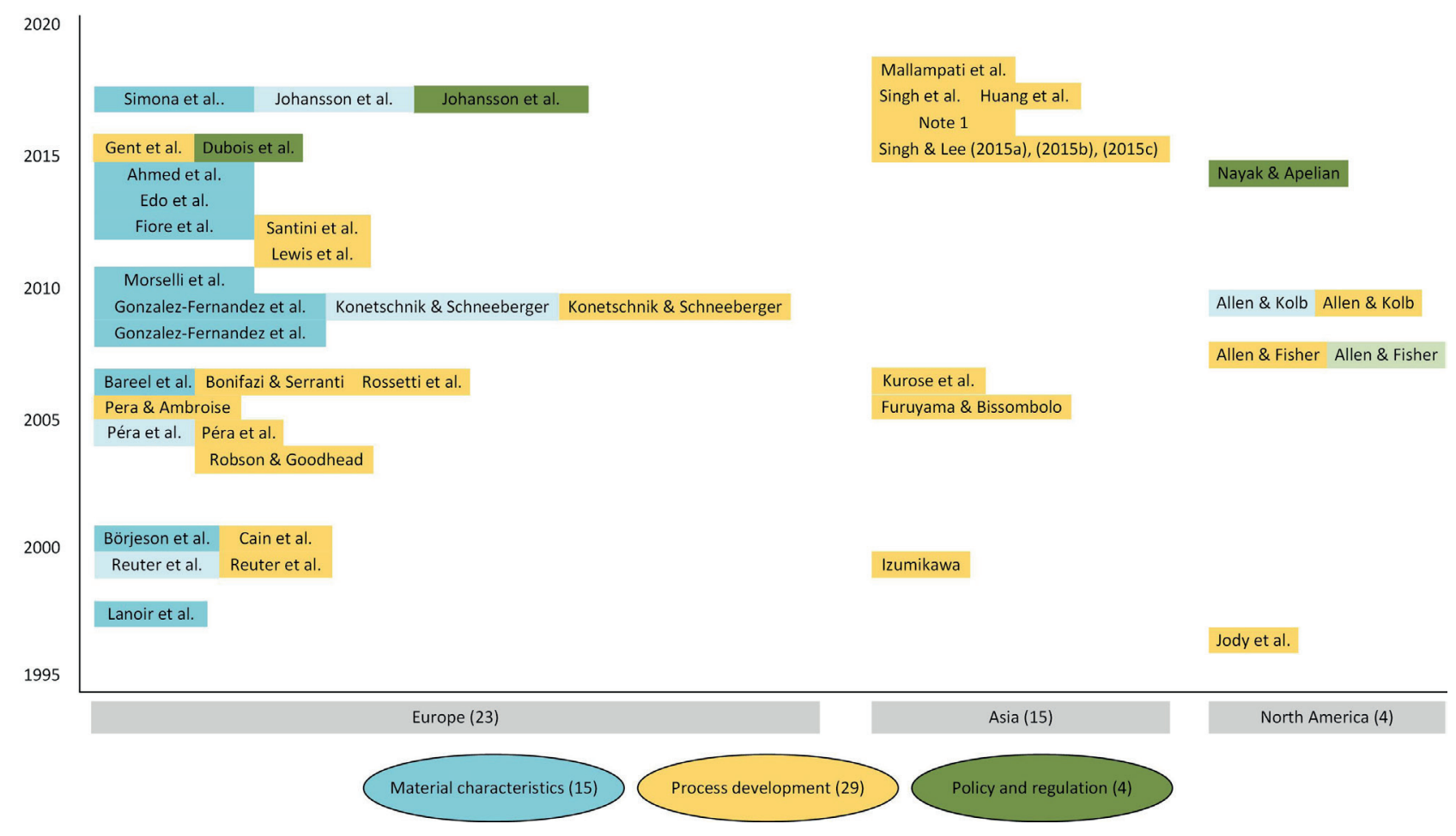

FIGURE 3: Temporal and geographical distribution of research work according to research topics. The dark colours represent literature where the respective research topic is the primary focus while the lighter colours indicate that the respective research topic has been performed with secondary focus. The number of articles is given within brackets region-wise and research topic-wise. Note 1: Mallampati et al. (Mallampati et al., 2016), Singh \& Lee (2016a), Singh \& Lee (2016b), Singh, Yang, et al. (2016c), Singh, Yang, et al. (2016b), and Singh, Chang, et al. (2016a).

TABLE 1: Categorisation of material characteristics literature based on research objectives (a total of 15 articles). The number of studies is given within brackets.

\begin{tabular}{|c|c|c|c|c|c|c|}
\hline \multicolumn{2}{|c|}{ Scope-related attributes } & \multicolumn{5}{|c|}{ Applicability-related attributes } \\
\hline Research objective & $\begin{array}{l}\text { Targeted materials/ } \\
\text { properties }\end{array}$ & Material origin & $\begin{array}{l}\text { Size fractions } \\
\text { analysed }\end{array}$ & $\begin{array}{l}\text { Total no. of } \\
\text { samples }\end{array}$ & $\begin{array}{l}\text { Total qty. } \\
\text { sampled }\end{array}$ & $\begin{array}{l}\text { Sampling } \\
\text { procedure }\end{array}$ \\
\hline \multirow{5}{*}{$\begin{array}{l}\text { Estimation of recov- } \\
\text { ery potential ( } 8 \text { ) }\end{array}$} & \multirow{5}{*}{$\begin{array}{l}\text { Base metals }^{\mathrm{a}}(7) \\
\text { Heavy metals }^{\mathrm{b}}(7) \\
\text { Alkali metals }(2) \\
\text { Alkaline (3) } \\
\text { Metalloids (3) } \\
\text { Inorganic compounds } \\
(3)^{\mathrm{c}} \\
\text { Organic compounds }^{\mathrm{d}(2)} \\
\text { Plastics (1) } \\
\text { Fuel properties }{ }^{\mathrm{e}}(3) \\
\text { Material fractions }^{\mathrm{f}}(2)\end{array}$} & $\begin{array}{l}\text { Denmark: two landfills } \\
\text { (1) }\end{array}$ & $<10 \mathrm{~mm}$ & Two & $20-40 \mathrm{~kg}$ & Strategic \\
\hline & & Italy: one plant (1) & $<20 \mathrm{~mm}$ & One & $50 \mathrm{~kg}$ & Non-systematic \\
\hline & & Belgium: one plant (1) & $<2 \mathrm{~mm}$ & Two & Unknown & Unknown \\
\hline & & Sweden: one landfill (1) & $<7 \mathrm{~mm}$ & Unknown & Unknown & Unknown \\
\hline & & Unknown (4) & $\begin{array}{l}<4 \mathrm{~mm}(2) \\
<19 \mathrm{~mm}(1) \\
<20 \mathrm{~mm}(1)\end{array}$ & Unknown & Unknown & Unknown \\
\hline \multirow{6}{*}{$\begin{array}{l}\text { Estimation of environ- } \\
\text { mental risk ( } 7)\end{array}$} & \multirow{6}{*}{$\begin{array}{l}\text { Base metals ( } 7) \\
\text { Heavy metals ( } 7) \\
\text { Organic compounds } \\
(2)\end{array}$} & Italy: two plants (1) & $<10 \mathrm{~mm}$ & Two & $20-30 \mathrm{~kg}$ & Representative \\
\hline & & Spain: two plants (2) & $<6 \mathrm{~mm}$ & Two & $16 \mathrm{~kg}$ & Non-systematic \\
\hline & & Slovakia: one plant (1) & $<10 \mathrm{~mm}$ & One & Unknown & Non-systematic \\
\hline & & Italy: one plant (1) & $<20 \mathrm{~mm}$ & Five & $16-18 \mathrm{~kg}$ & Non-systematic \\
\hline & & France: one plant (1) & $<20 \mathrm{~mm}$ & One & 50 lit & Non-systematic \\
\hline & & Sweden: two plants (1) & $<17 \mathrm{~mm}$ & Two & Unknown & Unknown \\
\hline
\end{tabular}

Studies focusing on the estimation of recovery potential:(Reuter et al., 1999), (Péra et al., 2004), (Bareel et al., 2006), (Allen and Kolb, 2009), (Konetschnik and Schneeberger, 2009), (Edo et al., 2013), (Ahmed et al., 2014), (Johansson et al., 2017).

Studies focusing estimation of environmental risk: (Lanoir et al., 1997), Börjeson (2000), (Gonzalez-Fernandez et al., 2008), (Gonzalez-Fernandez et al., 2009), (Morselli et al., 2010), (Fiore et al., 2012), (Simona et al., 2017).

a. Common metals that are recovered and traded in large scale. E.g. Fe, $\mathrm{Al}, \mathrm{Cu}, \mathrm{Zn}$

b. Metals in the periodic table ranging from scandium to bismuth, except for base metals, metalloids, Group I, and Group II.

c. Oxides, carbonates, and sulphates.

d. PCB, PAH, PCDD, and PCDF.

e. Properties that are commonly looked for in a fuel such as heat content, ash, moisture, chlorine, and sulphur.

f. Metals, plastics, and minerals (glass, stone, and sand). 
bottom ash research has additionally characterised the speciation of metals, e.g. oxides, carbonates, sulphates, and chlorides (Dou et al., 2017; Lam et al., 2010; Margallo et al., 2015). The speciation largely determines the mobility of metals, which in turn influences the efficiency of any recovery process or measures to reduce environmental risks of disposal. Studies on MSWI bottom ash have even investigated the inter-relations between the chemical form of occurrence and the mobility of different components in different conditions, such as ageing and varying $\mathrm{pH}$ levels.

Furthermore, the physical and mechanical properties, a particularly crucial factor in the bulk utilisation as a substitute material in construction applications, is absent in shredder fines research. In contrast, a myriad of such properties (e.g. density, permeability, porosity, compressive strength, Young's modulus, deformation strength, Secant moduli, effective fringe angle, surface rupture, and global shape factor) has been investigated in the bottom ash research (Dou et al., 2017; Le et al., 2017).

\subsubsection{Applicability-related limitations}

Current knowledge on the material characteristics of shredder fines is not only limited by the breadth and depth of the various properties studied, but also by what material was actually addressed. The employed sampling procedure is the main issue in this regard, where most of the studies have only involved a few, randomly collected samples of fines from a particular plant. Given that the properties of fines from a shredder plant could vary significantly over hours, weeks, months and years owing to fluctuations in the composition of the feed material, such ad-hoc sampling is only capable of providing a snapshot of the material characteristics of a continuous flow. This lack of understanding about the variation in chemical and physical properties is critical since such characteristics determine the technical efficiency and economic viability of any subsequent treatment or recovery process (Allegrini et al., 2014; European Commission, 2004). Even the few studies that have employed representative sampling of fines fail to address such variation in material characteristics because the results are merely reflecting average values. A close attempt to address the variation factor has been made by Ahmed et al. (2014), using samples from previously disposed of shredder residues. There, the samples were strategically collected and characterised in order to establish the annual variation over a decade. However, results from such samples only show the long-term development of the material characteristics of fines and not the shorter-term (weekly or monthly), which is more interesting for the development of resource recovery processes. Furthermore, due to the extensive focus on the development of a particular recovery process, information regarding the employed sampling procedure, and thus, what shredder fines were actually characterised, is lacking in several studies.

In essence, current knowledge about the material characteristics of fines is constrained to a few assessed samples taken from a largely limited number of shredder plants in Europe (Table 1). In total, only a few hundred kilograms of fines have been characterised during the last couple of decades, to be compared with the approximate- ly one million tonnes that are generated within this region annually (see Section 1). The need to develop a comprehensive knowledge on the material characteristics of fines, thus, not only calls for an analysis of a larger share of the generated amounts, but also stresses the importance of addressing the variations in physical and chemical properties on the plant, country, and regional levels. For instance, regarding MSWI bottom ash, such regional characteristics on, e.g. typical metal and metal oxide compositions have been established for European, Asian, and other countries (Dou et al., 2017), which enables the development of tailored valorisation measures in the respective levels.

\subsection{Process development}

The development of technical processes in previous research for managing shredder fines is categorised into three main groups: recovery of specific materials from fines, utilisation of fines as a substitute raw material, and reduction of environmental risk of fines disposal (Table 2). A majority of the studies in the first group involves the development of mechanical processes (e.g. shaker tables, jigs, eddy current separators) for the recovery of specific material fractions such as metals. These studies typically address resource recovery from the larger fractions of fines. Most of the studies belonging to the second group have investigated the utilisation of fines as a bulk material to substitute sand and gravel in construction-related applications. The dominating focus of the third group of studies is the solvent extraction of heavy metals. What the studies in these last two groups have in common is that they primarily target the smaller size fractions of fines.

\subsubsection{Scope-related limitations}

In general, the research has mainly developed processes focusing on one specific type of resource or contaminant. This is implied in that the studies are somewhat scattered in terms of the research objectives, types of studied processes/applications, and targeted resources (Table 2). The availability of a certain technology and required facilities at the researchers' disposal is a possible reason behind such narrowly conceived approaches to process development. Consequently, the development of integrated approaches for the full valorisation of fines has so far been largely overlooked. For instance, only 2 out of the 29 studies have investigated the integration of resource recovery and subsequent bulk utilisation of the rest as a substitute raw material (Jody et al., 1996; Konetschnik and Schneeberger, 2009). Furthermore, in studies on environmental risk reduction processes, the key target has been to enable final disposal rather than to upgrade fines to facilitate subsequent recovery. In essence, the number of studied processes and options for upgrading and recovery of shredder fines is yet limited. However, a vast domain of potential applications that could be used for integrated process development to facilitate full valorisation of fines could be identified by comparing against corresponding research on MSWI bottom ash management (Figure 4).

The mere consideration of a variety of potential processes and applications for the recovery of shredder fines would not be sufficient either. More in-depth assessments 
TABLE 2: Categorisation of process development literature based on research objective (a total of 29 articles). The number of studies is given within brackets. Some studies contain more than one research objective.

\begin{tabular}{|c|c|c|c|c|c|c|}
\hline \multicolumn{4}{|c|}{ Scope-related attributes } & \multicolumn{3}{|c|}{ Applicability-related attributes } \\
\hline $\begin{array}{l}\text { Research ob- } \\
\text { jective }\end{array}$ & $\begin{array}{l}\text { Type of process / } \\
\text { application }\end{array}$ & $\begin{array}{l}\text { Targeted resources/ } \\
\text { contaminants }\end{array}$ & $\begin{array}{l}\text { Studied process } \\
\text { attributes }\end{array}$ & Material origin & $\begin{array}{l}\text { Size fraction } \\
(\mathrm{mm})\end{array}$ & Scale \\
\hline \multirow{12}{*}{$\begin{array}{l}\text { Recovery of spe- } \\
\text { cific resources } \\
\text { (16) }\end{array}$} & \multirow{9}{*}{$\begin{array}{l}\text { Mechanical separation } \\
\text { a (9) }\end{array}$} & \multirow{3}{*}{$\begin{array}{l}\text { Metals as a material } \\
\text { fraction (3) }\end{array}$} & \multirow{3}{*}{$\begin{array}{l}\text { Operating parameters (1) } \\
\text { Recovery efficiency (3) } \\
\text { Economic feasibility (1) }\end{array}$} & Belgium: plant A (1) & $<2 \mathrm{~mm}$ & Lab \\
\hline & & & & Spain: plant A (1) & $<10 \mathrm{~mm}$ & Pilot \\
\hline & & & & Italy: plant A (1) & $<17 \mathrm{~mm}$ & Lab \\
\hline & & \multirow{3}{*}{$\begin{array}{l}\text { Plastics as a material } \\
\text { fraction (2) }\end{array}$} & \multirow{3}{*}{$\begin{array}{l}\text { Recovery efficiency (1) } \\
\text { Output characteristics ( } 1 \text { ) } \\
\text { Economic feasibility (1) }\end{array}$} & Italy: plant B (1) & $<20 \mathrm{~mm}$ & Lab \\
\hline & & & & $\begin{array}{l}\text { South Korea: plant } \\
\text { A (2) }\end{array}$ & $<0.25 \mathrm{~mm}$ & Lab \\
\hline & & & & $\begin{array}{l}\text { South Korea: plant } \\
\text { B (1) }\end{array}$ & $<1 \mathrm{~mm}$ & Lab \\
\hline & & \multirow{3}{*}{$\begin{array}{l}\text { Several material } \\
\text { fractions (4) }\end{array}$} & \multirow{3}{*}{$\begin{array}{l}\text { Operating parameters (2) } \\
\text { Recovery efficiency (3) } \\
\text { Output characteristics (2) } \\
\text { Economic feasibility (2) }\end{array}$} & $\begin{array}{l}\text { South Korea: plant } \\
\text { C (1) }\end{array}$ & $<4.75 \mathrm{~mm}$ & Lab \\
\hline & & & & Japan: plant A (1) & $<10 \mathrm{~mm}$ & Lab \\
\hline & & & & USA: plant A (1) & $<20 \mathrm{~mm}$ & Pilot \\
\hline & Smelting (2) & Base metals (2) & $\begin{array}{l}\text { Pre-treatment require- } \\
\text { ments }(1) \\
\text { Operating parameters (1) } \\
\text { Recovery efficiency }(1) \\
\text { Output characteristics }(1)\end{array}$ & \multirow{3}{*}{ Unknown (6) } & \multirow{3}{*}{$\begin{array}{l}<4 \mathrm{~mm}(1) \\
<6.2 \mathrm{~mm}(1) \\
<13 \mathrm{~mm}(1) \\
<19 \mathrm{~mm}(1) \\
<20 \mathrm{~mm}(2)\end{array}$} & \multirow{3}{*}{$\begin{array}{l}\text { Conceptual } \\
\text { Pilot } \\
\text { Unknown } \\
\text { Conceptual } \\
\text { Lab }\end{array}$} \\
\hline & Solvent extraction (4) & $\begin{array}{l}\text { Base metals (4) } \\
\text { Heavy metals ( } 3 \text { ) }\end{array}$ & $\begin{array}{l}\text { Operating parameters (4) } \\
\text { Recovery efficiency (4) } \\
\text { Output characteristics (3) }\end{array}$ & & & \\
\hline & Pyrolysis (1) & Fuels (1) & $\begin{array}{l}\text { Operating parameters (1) } \\
\text { Recovery efficiency (1) }\end{array}$ & & & \\
\hline \multirow{6}{*}{$\begin{array}{l}\text { Utilisation as } \\
\text { substitute raw } \\
\text { material (9) }\end{array}$} & \multirow{3}{*}{$\begin{array}{l}\text { Construction applica- } \\
\text { tions }{ }^{\mathrm{b}}(5)\end{array}$} & \multirow{3}{*}{ Shredder fines (5) } & \multirow{3}{*}{$\begin{array}{l}\text { Pre-treatment require- } \\
\text { ments (2) } \\
\text { Extent of utilisation (4) } \\
\text { Operating parameters (2) } \\
\text { Output characteristics (4) } \\
\text { Economic feasibility (1) }\end{array}$} & Italy: plant C (1) & $<4 \mathrm{~mm}$ & $\mathrm{Lab}$ \\
\hline & & & & UK: plant A (2) & $\begin{array}{l}<1 \mathrm{~mm}(1) \\
<3 \mathrm{~mm}(1)\end{array}$ & Lab \\
\hline & & & & $\begin{array}{l}\text { South Korea: plant } \\
\text { A (3) }\end{array}$ & $<0.25 \mathrm{~mm}$ & Lab \\
\hline & $\begin{array}{l}\text { Moulding of thermoplas- } \\
\text { tics (2) }\end{array}$ & Shredder fines (2) & $\begin{array}{l}\text { Operating parameters (1) } \\
\text { Extent of utilisation (2) } \\
\text { Output characteristics (2) }\end{array}$ & \multirow{3}{*}{ Unknown (3) } & \multirow{3}{*}{$\begin{array}{l}<4 \mathrm{~mm}(1) \\
<4 \mathrm{~mm}(1) \\
<6.2(1)\end{array}$} & \multirow{3}{*}{$\begin{array}{l}\text { Unknown } \\
\text { Conceptual } \\
\text { Pilot }\end{array}$} \\
\hline & \multirow{2}{*}{$\begin{array}{l}\text { Wastewater treatment } \\
(2)\end{array}$} & Magnetic fraction (1) & $\begin{array}{l}\text { Operating parameters (1) } \\
\text { Extent of utilisation (1) }\end{array}$ & & & \\
\hline & & Elemental metals (1) & $\begin{array}{l}\text { Operating parameters (1) } \\
\text { Extent of utilisation (1) } \\
\text { Output characteristics (1) }\end{array}$ & & & \\
\hline \multirow{5}{*}{$\begin{array}{l}\text { Environmental } \\
\text { risk reduction } \\
\text { (9) }\end{array}$} & Solvent extraction (6) & \multirow{5}{*}{$\begin{array}{l}\text { Base - \& heavy metals } \\
(9)\end{array}$} & \multirow{5}{*}{$\begin{array}{l}\text { Operating parameters (8) } \\
\text { Extent of utilisation (1) } \\
\text { Output characteristics (9) }\end{array}$} & $\begin{array}{l}\text { South Korea: plant } \\
\text { A (1) }\end{array}$ & $<0.25 \mathrm{~mm}$ & Lab \\
\hline & & & & South Korea: plant B & $<1 \mathrm{~mm}$ & Lab \\
\hline & $\begin{array}{l}\text { Mechanical separation } \\
\text { (1) }\end{array}$ & & & $\begin{array}{l}\text { South Korea: plant } \\
\text { C (5) }\end{array}$ & $<4.75 \mathrm{~mm}$ & Lab \\
\hline & $\begin{array}{l}\text { Chemical immobilisa- } \\
\text { tion (1) }\end{array}$ & & & $\begin{array}{l}\text { Japan: unknown } \\
\text { source }(1)\end{array}$ & $<4 \mathrm{~mm}$ & Industrial \\
\hline & $\begin{array}{l}\text { Physical immobilisation } \\
\text { (1) }\end{array}$ & & & Unknown(1) & $<4 \mathrm{~mm}$ & Lab \\
\hline
\end{tabular}

Studies focusing on the recovery of specific materials from fines:(Jody et al., 1996), (Reuter et al., 1999), (Izumikawa, 1999), (Furuyama and Bissombolo, 2005), (Bonifazi and Serranti, 2006), (Allen and Fisher, 2007), (Allen and Kolb, 2009), (Konetschnik and Schneeberger, 2009), (Lewis et al., 2011), (Santini et al., 2012), (Gent et al., 2015), (Singh et al., 2017), (Huang et al., 2017), and (Mallampati et al., 2018).

Studies focusing on the utilisation of fines as a substitute raw material: (Jody et al., 1996), (Cain et al., 2000), (Robson and Goodhead, 2003), (Péra et al., 2004), (Rossetti et al., 2006), (Konetschnik and Schneeberger, 2009), and (Singh et al., 2016a).

Studies focusing the reduction of environmental risk of fines: (Pera and Ambroise, 2005), (Kurose et al., 2006), Singh \& Lee (2015a), (Singh and Lee, 2015c),

(Singh and Lee, 2015b), (Singh and Lee, 2016a), (Singh and Lee, 2016b), (Mallampati et al., 2016), and (Singh et al., 2016c).

a. Consists of a series of mechanically operated unit operations that separate materials based on physical, magnetic, and electrical properties.

$b$. Consist of using fines as aggregate in concrete, aggregate in cement mortar, and raw material in cement production.

of the process attributes are equally important. For instance, in some of the processes displayed in Figure 4, it could be seen that both shredder fines and bottom ash have been investigated for a particular application. Howev- er, the research maturity and knowledge about the process attributes are substantially higher in the bottom ash literature. The different process attributes investigated in the fines literature are pre-treatment, recovery efficiencies, the 




FIGURE 4: Scope of process development research concerning bottom ash management and shredder fines. References concerning municipal solid waste incinerator bottom ash research: Kinto (1996), Lam et al. (Lam et al., 2010), Rahman \& Bakker (2012), Tanigaki et al. (2012), Rahman \& Bakker (2013), Margallo et al. (2015), Gao et al. (2015), Tang \& Steenari (2016), Dou et al. (2017), Silvia et al. (2017), Holm \& Simon (2017), Breitenstein et al. (2017), and Verbinnen et al. (2017).

extent of material substitution, operating parameters, and output characteristics (Table 2). Recovery efficiencies, the extent of material substitution, and the operating parameters (temperature, pressure, flow rates, mixing rates, etc.) are the most important attributes to enable the further development and feasibility assessment of processes as they determine both technical and economic feasibilities, and therefore, featured in all the studies. Pre-treatment, owing to the heterogeneity and high contamination levels, is an important attribute that is often required to upgrade fines and make them suitable for a particular application, yet, only three studies have addressed it. Characteristics of the outputs of a process are necessary to establish due to two main reasons. The first is to determine whether the outputs meet the user and regulatory requirements; the second is in the case of the potential integration of recovery processes, where outputs from one process become the input to another. The economic feasibility has been investigated in only five of the studies, despite being a necessary condition for the application in commercial scale. Furthermore, none of the studies have addressed all these attributes. The necessity to perform research specifically focused on some of the above process attributes - especially, recovery efficiencies and operating parameters - is understandable at this early phase of research in order to closely investigate the technical feasibility of processes. However, the realisation of the developed processes would not be successful unless all these attributes are addressed.

\subsubsection{Applicability-related limitations}

A particularly interesting aspect of the studies within the process development topic is that a majority of them (20 of 31 ) investigate processes on a laboratory scale. Four out of the five pilot-scale processes are from the resource recovery category and deal with the mechanical separation of specific materials from fines (Allen and Fisher, 2007; Gent et al., 2015; Izumikawa, 1999; Jody et al., 1996), while the remaining one represents material substitution in construction applications (Jody et al., 1996). The only process that is studied on an industrial scale is the mechanical separation of heavy metals to reduce the environmental risks of fines disposal (Kurose et al., 2006). Three processes have been developed on a conceptual basis, plausibly emanating from the knowledge and experience of the authors, and the scale of operation remains unknown in two.

The applicability of the results obtained from lab-scale process development is limited for several reasons (Mankins, 1995). One is the effect of changing process conditions when the scale of operation is increased. An example of this is the metals recovery by smelting as a pyro-metal- 
lurgical process. Even though a recovery as high as $98 \%$ was reported for $\mathrm{Cu}$ and Fe when tested on lab scale, a dynamic system such as smelting may not reach an equilibrium between the three phases (metal, slag, and gas) on an industrial scale, thus affecting the outcome (Reuter et al., 1999). Another major limitation of process development on a lab scale is the inability to assess the investment and operating costs. The possibility of overlooking the influence of supply chain factors, which are crucial on an industrial scale, is another drawback of being limited to lab-scale tests. For example, Cain et al. (2000) have investigated the use of fines in co-injection moulding to produce composite moulds comprised of shredder residue core and polypropylene (PP) skin. However, essential physical properties such as compressive strength and thermal stability depend on the material characteristics and quality of shredder fines, which in turn depends on the source for that material. Therefore, fines from different shredder plants (instead of one single source) need to be tested because an industrial-scale operation would most likely require the supply from multiple sources.

Regardless of the studied scale of operation, a common applicability-related issue of the studies within this topic is that they typically base the process development on a specific type or even sample of shredder fines. This means that the process efficiency and performance for the upgrading and resource recovery of other fines, with significantly different material properties, are largely uncertain. Yet, in the reviewed studies, information about the origin of the fines used for process development and their specific characteristics are often scarce - something which makes it increasingly difficult to evaluate the applicability of the results.

\subsection{Policy and regulation}

The research within this topic is divided into two main categories (Table 3). In the first category, the focus is on how different governmental policies could influence incentives for the valorisation of shredder residues (not limited to fines) and increase the competitiveness of the secondary resources derived from this material. These studies apply a top-down and macro-level (shallow yet broader knowledge on a regional/national level) approach to the implications of policy and regulation. Research within the second category instead stems from a micro-level perspec- tive, targeting specific shredder plants and the assessment of the marketability of fines-derived resources (FDRs) such as ferrous metals, non-ferrous metals, plastics, and minerals (sand, stone, gravel, and glass). These studies provide deeper insights on factors such as local institutional regulations for using secondary raw materials and gate requirements of potential users of FDRs.

\subsubsection{Scope-related limitations}

The knowledge provided by the studies on the macro level is somewhat superficial as it mainly involves anticipated implications of existing or suggested policy instruments. This knowledge is limited due to the small number of studies that could only investigate a few policy-related issues out of many. Comparing this with the MSWI bottom ash literature reveals several other macro-level implications such as policy influence on material composition (Lee et al., 2014) and triggering resource recovery (Born, 1994), and governmental decision making to facilitate valorisation (Huang et al., 2006). Regarding the micro-level studies, in addition to the small number of studies, a significant limitation is that they address the implications on secondary materials rather generally and are confined to regulatory requirements. In contrast, detailed investigations on micro-level implications, including marketability-related aspects beyond the regulatory requirements such as supply, demand, and competition in relation to specific applications of secondary materials, is evident in the MSWI bottom ash research (Vorobieff, 2010).

Additionally, the studies within this topic lack an understanding of how the involved actors interpret and react to different policy stimuli, which is paramount in putting policy into practice. Such complementation of the micro-level perspective with macro-level policy studies is evident in the MSWI bottom ash research (Born and Veelenturf, 1997; van der Zwan, 1997).

\subsubsection{Applicability-related limitations}

The main feature that limits the applicability of the two macro-level studies is that the focus has been on shredder residues in general rather than on shredder fines. Thereby, the understanding of the implications of current policies on the valorisation of shredder fines has become marginalised. However, the general applicability of the findings, irrespective of the region of focus in the study, is an ad-

TABLE 3: Categorisation of policy and regulation literature based on the research objective (a total of 4 articles). The number of studies is given within brackets.

\begin{tabular}{|c|c|c|c|c|}
\hline \multicolumn{3}{|l|}{ Scope-related attributes } & \multicolumn{2}{|c|}{ Applicability-related attributes } \\
\hline Research objective & Governing level & Studied policy and regulation implications & Region of study & Type of material \\
\hline $\begin{array}{l}\text { Study the implications of } \\
\text { governmental policy (2) }\end{array}$ & Macro (2) & $\begin{array}{l}\text { Role of waste-based policies as drivers and barriers } \\
\text { of valorisation (1) } \\
\text { Influence of market-based policies to create com- } \\
\text { petitiveness for secondary materials (1) }\end{array}$ & $\begin{array}{l}\text { USA (1) } \\
\text { EU (2) } \\
\text { Belgium (1) }\end{array}$ & Shredder residue \\
\hline $\begin{array}{l}\text { Study the implications of } \\
\text { institutional regulation ( } 2 \text { ) }\end{array}$ & Micro (2) & $\begin{array}{l}\text { Potential users of recovered materials and gate } \\
\text { requirements }(2) \\
\text { Regulatory requirements for use of fines as a raw } \\
\text { material in construction applications ( } 2 \text { ) }\end{array}$ & $\begin{array}{l}\text { Sweden (1) } \\
\text { California state (1) }\end{array}$ & Shredder fines \\
\hline
\end{tabular}

Studies focusing on regulatory conformance of valorisation measures: (Allen and Fisher, 2007) and (Johansson et al., 2017).

Studies focusing on policy implications of valorisation measures: (Nayak and Apelian, 2014) and (Dubois et al., 2015). 
vantage of typical top-down macro-level policy studies. For example, the insights created on policy instruments such as disposal tax, tradeable recycling credits, and refunded disposal tax could be generally considered as a means for increasing the competitiveness of local recyclers (Dubois et al., 2015). Additionally, such studies can compare the driver- and barrier-effects of policy between regions, e.g. Europe and the USA (Nayak and Apelian, 2014).

In contrast, the particulars of micro-level studies can fluctuate substantially depending on the locality (e.g. state, county, or municipality) involved, and therefore, unlike its former counterpart, the applicability is geographically confined. Nevertheless, such knowledge is necessary to highlight the implications of different governing approaches for the handling of uncertainties and conflicts of interests between resource-efficiency and risk-mitigation objectives in different localities, and thereby, to develop locality-specific valorisation applications. For instance, country-specific standards have been implemented for the reutilisation of MSWI bottom ash in ground construction applications such as road base layer, parking lots, pavements, etc. Certain countries, e.g. Germany, Denmark, and Taiwan, have specified the minimum distance from drinking water sources and minimum elevation from groundwater sources, whereas other countries, e.g. Japan, Denmark, and the Netherlands, have specified the maximum allowed quantity and thickness (Dou et al., 2017; Van Gerven et al., 2005).

\section{FUTURE RESEARCH GUIDANCE ON THE VALORISATION OF SHREDDER FINES}

A prominent feature of the previous research on shredder fines is that the studies have often been performed in isolation within the individual topics. In such isolated topical research, not only the significance of the aspects of other topics is overlooked, but also the various inter-relations between them. Nonetheless, the valorisation of a heterogeneous material such as fines involves the interaction of the different topical aspects on different levels. Hence, a systemic approach that acknowledges such inter-relations (Figure 5) is deemed necessary to complement topical research (Andersson et al., 2019; lacovidou et al., 2017) concerning fines management.
The valorisation of fines essentially involves process development to derive marketable fractions via exploiting the recovery potential and resolving the material constraints. Ragarding that, the key limitation of the previous research is that the process development has primarily taken place to address one specific resource opportunity (e.g. recovery of valuable metals) or material constraint (e.g. removal of heavy metals) at a time. Additionally, there, the investigation of material constraints is further confined to being used as a means for environmental risk reduction for (landfill) disposal, rather than for the identification of the need for upgrading for subsequent recovery. The aforementioned narrow approach to process development is also reflected in the approaches undertaken in material characterisation in previous studies. There, the established material properties are generally limited to a single type of resource (often base metals) or contaminants (often heavy metals). Such characterisation would not facilitate the process development to harness the full valorisation (the recovery of valuable resources as well as the utilisation of the whole of the material) potential. Furthermore, these studies have predominantly employed an ad-hoc collection of one or two samples, which would not reveal the over-time variation of composition that provides essential process design information. Consequently, the developed processes risk ending up redundant. It is also understood that research concerning shredder fines is still in an early phase where it is natural to investigate a particular topic in detail. Yet, the process development for the valorisation of such a heterogeneous residue needs to emanate from a comprehensive understanding of the material characteristics (a, Figure 5). That is, not only an array of chemical and physical properties is established, but also their distribution across the different size fractions and the over-time variation of the composition (Hernández Parrodi et al., 2018b). Such characterisation would facilitate the identification of the resource and contamination potential fully. Thereby, potential users of fines-derived resources (FDRs) could be identified for a variety of applications in order to not only avoid missing good valorisation opportunities but also aid in the integration of different types of recoveries to facilitate full valorisation (b, Figure 5 ). Then, their quality specifications (market requirements) could be established and



Actors' incentives and capacities

FIGURE 5: The systemic view of shredder fines valorisation. The arrows represent the inter-relations between the different research topics and other aspects concerning fines valorisation that have not been specifically addressed in previous research. a: Knowledge on material characteristics to enable process development; b: Knowledge on quality requirements of users of fines-derived resources, to enable process development; c: Knowledge on material characteristics to identify potential users of fines-derived resources. 
the upgrading requirements to address the corresponding material constraints identified (c, Figure 5). Such a user requirement-based approach to process development, which is necessary to produce marketable outputs, is absent in the previous literature.

It is also quite natural to observe process development on a lab scale in an early phase of research. However, in order to ensure applicability, the results obtained it such studies need substantiation on a larger scale (e.g. pilot- or industrial-scale) (Mankins, 1995). Furthermore, associated sustainability concerns such as environmental impacts, costs of the involved processes, and income/savings from valorised products could simultaneously be considered as part of process development. Examples are the identification of particularly significant environmental impacts (hotspots) (Joyce et al., 2018), and key sources (material and energy inputs) of such impacts and potential substitutes (Joyce and Björklund, 2019).

Knowledge on drivers and barriers for initiating valorisation needs to be a key element as well in future research concerning fines management. There, the context of policy and regulation, and actors' (suppliers and users of FDRs) incentives and capacities play a vital role as governing conditions of fines valorisation. For instance, the implications of governmental waste policies on fines valorisation need to be established: that is, to what extent are the current policies reflected in legislation, and how are they implemented via institutional regulation practices? For example, in Sweden, significant uncertainties exist among the local institutions regarding what quality requirements actually rule in different situations and settings concerning the use of secondary materials, despite the EU and national policies for increased resource efficiency. Consequently, the high environmental and human health risk of contaminants in secondary resources is preconceived, and over-prudent limits on contamination levels are imposed (Johansson et al., 2017), which pose a major challenge in producing marketable FDRs. Providing insights on anticipated future policy changes is also important. In order to understand the real implications of different policy instruments (existing or anticipated) in practice, top-down approaches need to be complemented by bottom-up research, targeting how the shredding companies and potential users of FDRs would interpret different policy stimuli (micro-level), and in what capacities they would react. Such an in-depth understanding is crucial in the development of necessary policy interventions to both facilitate the technology development for fines valorisation and foster the marketability of FDRs. The significance of this perspective in accurately ascertaining the potential of residue valorisation has also been recognised in relation to the valorisation of MSWI bottom ash (Ribbing, 2007) and other types of industrial residues (Johansson et al., 2012; van Beers et al., 2009; Van Gerven et al., 2005). Some authors (Allen and Fisher, 2007; Johansson et al., 2017) have slightly touched upon these aspects concerning fines valorisation via establishing the gate requirements of potential users of FDRs; nevertheless, this area of knowledge, to a large extent, remains a gap in the literature. On the other hand, understanding the marketability of FDRs is incomplete without knowledge of the market forces at play and the dynamics of business development between shredding companies and users of FDRs. The former constitutes the structural elements of the market such as the current flows of shredder fines and their future prognosis, potential user demands on FDRs, and competition from other (often primary) resources (Porter, 1985, 1980). The latter consists of organisational aspects such as business strategies, value orientations, culture, and learning processes since it involves a change in current practices for both organisations under a new business contract (Peschl, 2007; Pettigrew, 2012). Without a thorough understanding of such market and organisational aspects, the true marketability of FDRs would not be assessed. Thus, endeavours for the valorisation of fines are unlikely to be realised and sustained.

\section{CONCLUSIONS}

The knowledge created in previous literature concerning shredder fines, in general, is scattered and incoherent. The main contribution of this article was to develop a coherent overview and an assessment of the previous research on shredder fines, and thereby, facilitate future research concerning its valorisation. The previous literature has collectively contributed to the development of various domains of knowledge, especially regarding specifics on the individual research topics, which is essential for the upgrading and recovery of shredder fines. Nevertheless, it also unveils a significant potential for improvement in the same regard.

Material characteristics studies are almost limited to a few common materials and elements, primarily revolving around the metal content. Comprehensive knowledge of the chemical and physical properties is required to establish the resource and contamination potential fully. There, undertaking strategic sampling procedures to capture the variation in composition is of paramount significance, as ad-hoc sampling is inadequate to do so. Process development studies have often taken place with narrowly conceived objectives, i.e. addressing one resource opportunity or contamination problem at a time. In order to facilitate full valorisation, it is crucial to identify a variety of valorisation alternatives and the potential for their integration. Furthermore, the substantiation of lab-scale results in larger-scale operations is essential to make the findings more applicable. Incorporating environmental impact and economic aspects already in the early phase of process development is also recommended to ensure sustainability, which is an aspect missing almost entirely in the previous research.

The main limitation of the policy and regulation studies is that the macro and micro levels have been investigated in insolation. Understanding the influence of governmental waste policies and institutional regulation on actors' incentives and capacities to produce and use FDRs serves a critical aspect of facilitating both technology development for fines valorisation and marketability of FDRs. There, the complementation of top-down research (macro-level) with actor-level implications (micro-level) is vital. Other aspects concerning marketability, such as the structural elements 
of the market for FDRs and the dynamics of business development between their suppliers and users, remain almost entirely absent in the previous literature.

Isolated topic-specific research is perhaps necessary at an early phase of knowledge development; nevertheless, the realisation of shredder fines valorisation is an outcome of various aspects, within the different topics, acting together influencing each other. Therefore, future research needs to undertake a systems perspective that shows this bigger picture, comprehending not only the significance of the individual topics but as importantly their inter-relations. It also facilitates the internalisation of the inter-relations of the different aspects into topical research.

\section{ACKNOWLEDGEMENTS}

Financial support from the Swedish Foundation for Strategic Environmental Research (Mistra) is gratefully acknowledged.

\section{REFERENCES}

Ahmed, N., Wenzel, H., Hansen, J.B., 2014. Characterization of Shredder Residues generated and deposited in Denmark. Waste Manag. 34, 1279-1288. https://doi.org/10.1016/j.wasman.2014.03.017

Allegrini, E., Maresca, A., Emil, M., Sommer, M., Boldrin, A., Fruergaard, T., 2014. Quantification of the resource recovery potential of municipal solid waste incineration bottom ashes. Waste Manag. 34, 1627-1636. https://doi.org/10.1016/j.wasman.2014.05.003

Allen, L.E., Fisher, M.M., 2007. Metal Recovery from Shredder Residue Fines. J. Mater. Manuf. 156, 154-160.

Allen, T., Kolb, J., 2009. Benefits of Holistic Shredder Residue Recovery: Mechanical Recycling and Energy Recovery, in: International Thermal Treatment Technologies (IT3) \& Hazardous Waste Combustors (HWC) Joint Conference 2009. pp. 484-491.

Andersson, M., Söderman, M.L., Sandén, B.A., 2019. Adoption of systemic and socio-technical perspectives in waste management, WEEE and ELV research. Sustainability 11. https://doi.org/10.3390/ su11061677

Bareel, P.-F., Bastin, D., Bodson, C., Frenay, J., 2006. Sampling of Fine Shredder Residues (FSR) and characterisation oriented to physical separations, in: Kongoli, F., R.G, R. (Eds.), Sohn International Symposium Advanced Processing of Metals and Materials 2006. The Minerals Metals and Materials Society, San Diego, Caliofrnia, pp. 359-372.

Bonifazi, G., Serranti, S., 2006. Hyperspectral imaging based techniques in fluff characterization, in: Proceedings of SPIE 6377, Advanced Environmental, Chemical, and Biological Sensing Technologies. Boston. https://doi.org/10.1117/12.684661

Börjeson, L., Löfvenius, G., Hjelt, M., Johansson, S., Marklund, S., 2000. Characterization of automotive shredder residues from two shredding facilities with different refining processes in Sweden. Waste Manag. Res. 18, 358-366. https://doi. org/10.1177/0734242X0001800408

Born, J.G.P. 1994. Quantities and Qualities of Municipal Waste Incinerator Residues in The Netherlands. Environ. Asp. Constr. with Waste Mater. 60, 633-644.

Born, J.G.P., Veelenturf, R.A.L., 1997. MSWI residues in The Netherlands putting policy into practice. Waste Mater. Constr. Putt. Theory into Pract. 71, 841-850. https://doi.org/10.1016/S01661116(97)80269-5

Breitenstein, B., Elwert, T., Goldmann, D., Haas, A., Schirmer, T., Vogt, V., 2017. Froth Flotation of Copper and Copper Compounds from Fine Fractions of Waste Incineration Bottom Ashes. Chemie-IngenieurTechnik 89, 97-107. https://doi.org/10.1002/cite.201600017

Cain, R.L., Goodship, V., Love, J.C., Smith, G.F., Tucker, N., 2000 Recycling of Automotive Shredder Residue (ASR) by co-injection moulding. Polym. Recycl. 5, 63-70.

Cossu, R., Fiore, S., Lai, T., Luciano, A., Mancini, G., Ruffino, B., Viotti, P., Zanetti, M.C., 2014. Review of Italian experience on automotive shredder residue characterization and management. Waste Manag. 34, 1752-1762. https://doi.org/10.1016/j.wasman.2013.11.014
Cossu, R., Lai, T., 2015. Automotive shredder residue (ASR) management: An overview. Waste Manag. 45, 143-151. https://doi. org/10.1016/j.wasman.2015.07.042

Cronin, P., Kelly, A.M., Altaee, D., Foerster, B., Petrou, M., Dwamena, B.A., 2018. How to Perform a Systematic Review and Meta-analysis of Diagnostic Imaging Studies. Acad. Radiol. 25, 573-593. https:// doi.org/10.1016/j.acra.2017.12.007

Dou, X, Ren, F, Nguyen, M.Q., Ahamed, A, Yin, K, Chan, W.P., Chang, V.W.C., 2017. Review of MSWI bottom ash utilization from perspectives of collective characterization, treatment and existing application. Renew. Sustain. Energy Rev. 79, 24-38. https://doi. org/10.1016/j.rser.2017.05.044

Dubois, M., Hoogmartens, R., Van Passel, S., Van Acker, K., Vanderreydt, I., 2015. Innovative market-based policy instruments for waste management: A case study on shredder residues in Belgium. Waste Manag. Res. 33, 886-893. https://doi. org/10.1177/0734242X15600053

Edo, M., Aracil, I., Font, R., Anzano, M., Fullana, A., Collina, E., 2013. Viability study of automobile shredder residue as fuel. J. Hazard. Mater. 260, 819-824. https://doi.org/10.1016/j.jhazmat.2013.06.039

European Commission, 2008. Directive 2008/98/EC of the European Parliament and of the Council of 19 November 2008 on waste and repealing certain Directives, Official Journal of the Europian Union.

European Commission, 2004. Methodology for the Analysis of Solid Waste (SWA-Tool) User Version. Vienna.

European Commission, 2000. Directive 2000/53/EC of The European Parliament and of the Council of 18 September2000 on end-of life vehicles. Communities 6, 34-42. https://doi.org/10.1016/j.jclepro.2010.02.014

Fiore, S., Ruffino, B., Zanetti, M.C., 2012. Automobile Shredder Residues in Italy: Characterization and valorization opportunities Waste Manag. 32, 1548-1559. https://doi.org/10.1016/j.wasman.2012.03.026

Fischer, T., 2006. Getting a return from residue. Scrap 63, 57-62.

Furuyama, T., Bissombolo, A., 2005. Recovery of Copper from Light ASR Materials by Dry Towermilling and Electrostatic Separation, in: European Metallurgical Conference, EMC 2005. GDMB-Medienverl, Dresden.

Gao, B., Fedje, K.K., Strömvall, A.M., 2015. Phosphorus recovery from sorted municipal solid waste incineration ash. Solid waste Technol. Manag. 41, 249-261.

Gent, M.R., Menéndez, M., Muñiz, H., Torno, S., 2015. Recycling of a fine, heavy fluff automobile shredder residue by density and differential fragmentation. Waste Manag. 43, 421-433. https://doi. org/10.1016/j.wasman.2015.06.010

Gonzalez-Fernandez, O., Hidalgo, M., Margui, E., Carvalho, M.L., Queralt, I., 2008. Heavy metals' content of automotive shredder residues (ASR): Evaluation of environmental risk. Environ. Pollut. 153, 476482. https://doi.org/10.1016/j.envpol.2007.08.002

Gonzalez-Fernandez, O., Pessanha, S., Queralt, I., Carvalho, M.L., 2009. Analysis of lead content in automotive shredder residue (ASR). Waste Manag. 29, 2549-2552. https://doi.org/10.1016/j.wasman.2009.05.003

Hansen, W., Christopher, M., Verbuecheln, M., 2002. EU Waste Policy and Challenges for Regional and Local Authorities. Berlin.

Hernández Parrodi, J.C., Höllen, D., Pomberger, R., 2018a. Potential and Main Technological Challenges for Material and Energy Recovery From Fine Fractions of Landfill Mining: a Critical Review. Detritus In Press, 1. https://doi.org/10.31025/2611-4135/2018.13689

Hernández Parrodi, J.C., Höllen, D., Pomberger, R., 2018b. Characterisation of Fine Fractions from Landfill Mining: A Review of Previous Investigations $02,46-62$.

Holm, O., Simon, F.G., 2017. Innovative treatment trains of bottom ash (BA) from municipal solid waste incineration (MSWI) in Germany. Waste Manag. 59, 229-236. https://doi.org/10.1016/j.wasman.2016.09.004

Huang, C.M., Yang, W.F., Ma, H.W., Song, Y.R., 2006. The potential of recycling and reusing municipal solid waste incinerator ash in Taiwan. Waste Manag. 26, 979-987. https://doi.org/10.1016/j. wasman.2005.09.015

Huang, J., Tian, C., Ren, J., Bian, Z., 2017. Study on impact acousticvisual sensor-based sorting of ELV plastic materials. Sensors 17. https://doi.org/10.3390/s17061325

lacovidou, E., Millward-Hopkins, J., Busch, J., Purnell, P., Velis, C.A., Hahladakis, J.N., Zwirner, O., Brown, A., 2017. A pathway to circular economy: Developing a conceptual framework for complex value assessment of resources recovered from waste. J. Clean. Prod. 168, 1279-1288. https://doi.org/10.1016/j.jclepro.2017.09.002 
Izumikawa, C., 1999. Metal recovery from ash of automobile shredder residue - Especially focusing on particle shape, in: Gaballah, I. Hager, J., Solozabal, R. (Eds.), REWAS'99: Global Symposium on Recycling, Waste Treatment, and Clean Technology. The Minerals Metals and Materials Society.

Jody, B.J., Daniel, E.J., Pomykala Jr., J.A., 1996. Progress in recycling of automobile shredder residue. Argonne, Illinois.

Johansson, N., Krook, J., Eklund, M., 2012. Transforming dumps into gold mines. Experiences from Swedish case studies. Environ. Innov. Soc. Transitions 5, 33-48. https://doi.org/10.1016/j. eist.2012.10.004

Johansson, N., Krook, J., Frändegård, P., 2017. A new dawn for buried garbage? An investigation of the marketability of previously disposed shredder waste. Waste Manag. 60, 417-427. https://doi. org/10.1016/j.wasman.2016.05.015

Joyce, P.J., Björklund, A., 2019. Using Life Cycle Thinking to Assess the Sustainability Benefits of Complex Valorization Pathways for Bauxite Residue. J. Sustain. Metall. 5, 69-84. https://doi.org/10.1007/ s40831-019-00209-x

Joyce, P.J., Hertel, T., Goronovski, A., Tkaczyk, A.H., Pontikes, Y., Björklund, A., 2018. Identifying hotspots of environmental impact in the development of novel inorganic polymer paving blocks from bauxite residue. Resour. Conserv. Recycl. 138, 87-98. https://doi. org/10.1016/j.resconrec.2018.07.006

Kinto, K., 1996. Ash melting system and reuse of products by ARC processing. Waste Manag. 16, 423-430. https://doi.org/10.1016/ S0956-053X(96)00088-8

Konetschnik, D.S., Schneeberger, G., 2009. Recovery of Copper and Precious Metals from Shredder Residues, in: Harre, J. (Ed.), Proceedings of European Metallurgical Conference, 2009. ClausthalZellerfeld, Innsbruck, Austria, pp. 661-672.

Kurose, K., Okuda, T., Nishijima, W., Okada, M., 2006. Heavy metals removal from automobile shredder residues (ASR). J. Hazard. Mater. 137, 1618-1623. https://doi.org/10.1016/j.jhazmat.2006.04.049

Lam, C.H.K., Ip, A.W.M., Barford, J.P., McKay, G., 2010. Use of incineration MSW ash: A review. Sustainability 2, 1943-1968. https://doi. org/10.3390/su2071943

Lanoir, D., Trouvé, G., Delfosse, L., Froelich, D., Kassamaly, A. 1997. Physical and Chemical Characterization of Automotive Shredder Residues. Waste Manag. Res. https://doi. org/10.1177/0734242X9701500305

Le, N.H., Abriak, N.E., Binetruy, C., Benzerzour, M., Nguyen, S.T., 2017. Mechanical behavior of municipal solid waste incinerator bottom ash: Results from triaxial tests. Waste Manag. 65, 37-46. https:// doi.org/10.1016/j.wasman.2017.03.045

Lee, W.C., Shin, D.C., Dong, J.I., 2014. Investigation of characteristics of incinerator bottom ash and assessment for recycle due to the change of MSW composition. Appl. Chem. Eng. 25, 103-106. https://doi.org/10.14478/ace.2014.1007

Lewis, G., Gaydardzhiev, S., Bastin, D., Bareel, P.F., 2011. Bio hydrometallurgical recovery of metals from Fine Shredder Residues. Miner. Eng. 24, 1166-1171. https://doi.org/10.1016/j.mineng.2011.03.025

Mallampati, S.R., Lee, B.H., Mitoma, Y., Simion, C., 2018. Sustainable recovery of precious metals from end-of-life vehicles shredder residue by a novel hybrid ball-milling and nanoparticles enabled froth flotation process. J. Clean. Prod. 171, 66-75. https://doi. org/10.1016/j.jclepro.2017.09.279

Mallampati, S.R., Lee, B.H., Mitoma, Y., Simion, C., 2016. Dual mechanochemical immobilization of heavy metals and decomposition of halogenated compounds in automobile shredder residue using a nano-sized metallic calcium reagent. Environ. Sci. Pollut. Res. 23 22783-22792. https://doi.org/10.1007/s11356-016-7458-7

Mankins, J.C., 1995. Technology Readiness Levels, A White Paper, NASA

Margallo, M., Taddei, M B.M., Hernández-Pellón, A, Aldaco, R., Irabien, Á., 2015. Environmental sustainability assessment of the management of municipal solid waste incineration residues: A review of the current situation. Clean Technol. Environ. Policy 17, 13331353. https://doi.org/10.1007/s10098-015-0961-6

Morselli, L., Santini, A., Passarini, F., Vassura, I., 2010. Automotive shredder residue (ASR) characterization for a valuable management. Waste Manag. 30, 2228-2234. https://doi.org/10.1016/j. wasman.2010.05.017

Nayak, N., Apelian, D., 2014. Opportunities and Barriers to Resource Recovery and Recycling from Shredder Residue in the United States. Jom 66, 2367-2376. https://doi.org/10.1007/s11837-014-0902-6
Pera, J., Ambroise, J., 2005. Stabilization of automotive shredder residue by calcium sulfoaluminate cement, in: I, G., Mishra, R., Solosabal, M., Tanaka, M. (Eds.), REWAS '04: Global Symposium on Recycling, Waste Treatment and Clean Technology. Minerals, Metals \& Materials Society, Madrid, Spain, pp. 13-18.

Péra, J., Ambroise, J., Chabannet, M., 2004. Valorization of automotive shredder residue in building materials. Cem. Concr. Res. 34, 557-562. https://doi.org/10.1016/j.cemconres.2003.09.004

Peschl, M.F., 2007. Triple loop learning as foundation for profound change, individual cultivation, and radical innovation: Construction processes beyond scienti $c$ and rational knowledge. Constr. Found. 2, 136-145.

Pettigrew, A.M., 2012. Context and Action in the Transformation of the Firm_A reprise. J. Manag. Stud. 49, 1304-1328. https://doi. org/10.1111/j.1467-6486.2012.01054.x

Porter, M.E., 1985. Competitive Advantage: Creating and Sustaining Superior Performance. The Free Press, New York

Porter, M.E., 1980. Competitive strategy: Techniques for analyzing industries and competitors. The Free Press, New York.

Rahman, M.A., Bakker, M.C.M., 2013. Sensor-based control in eddy current separation of incinerator bottom ash. Waste Manag. 33, 1418-1424. https://doi.org/10.1016/j.wasman.2013.02.013

Rahman, M.A., Bakker, M.C.M., 2012. Hybrid sensor for metal grade measurement of a falling stream of solid waste particles. Waste Manag. 32, 1316-1323. https://doi.org/10.1016/j.wasman.2012.03.012

Reuter, M.A., Pieterse, M.V., Dalmijn, W.L., 1999. Is the Purometallurgical recovery of the Inorganic Material an Option for Automobile Shredder Residue, in: Gaballah, I., Hager, J., SoloZabal, R. (Eds.), Rewas'99: Global Symposium on Recycling, Waste Treatment and Clean Technology (Vol. II, Pp. 1787-1797). Minerals, Metals \& Materials Society, San Sebastian, Spain.

Ribbing, C., 2007. Environmentally friendly use of non-coal ashes in Sweden. Waste Manag. 27, 1428-1435. https://doi.org/10.1016/j. wasman.2007.03.012

Robson, S., Goodhead, T.C., 2003. A process for incorporating automotive shredder residue into thermoplastic mouldings. J. Mater Process. Technol. 139, 327-331. https://doi.org/10.1016/S09240136(03)00549-1

Rocha, M., Searcy, C., Karapetrovic, S., 2007. Integrating Sustainable Development into Existing Management Systems. Total Qual. Manag. Bus. Excell. 18, 83-92. https://doi. org/10.1080/14783360601051594

Rossetti, V.A., Di Palma, L., Medici, F., 2006. Production of aggregate from non-metallic automotive shredder residues. J. Hazard. Mater 137, 1089-1095. https://doi.org/10.1016/j.jhazmat.2006.03.048

Sabatier, P.A., 2019. Top-down and Bottom-up Approaches to Implementation Research : A Critical Analysis and Suggested Synthesis. J. Public Policy 6, 21-48.

Santini, A., Passarini, F., Vassura, I., Serrano, D., Dufour, J., Morselli, L., 2012. Auto shredder residue recycling: Mechanical separation and pyrolysis. Waste Manag. 32, 852-858. https://doi.org/10.1016/j. wasman.2011.10.030

Scopus, 2018. Scopus [WWW Document]. Elsevier. URL https://www elsevier.com/solutions/scopus (accessed 10.27.17)

Silva, R. V., de Brito, J., Lynn, C.J., Dhir, R.K., 2017. Use of municipal solid waste incineration bottom ashes in alkali-activated materials ceramics and granular applications: A review. Waste Manag. 68 207-220. https://doi.org/10.1016/j.wasman.2017.06.043

Simona, S.-F., Havlik, T., Miskufova, A., 2017. Recycling of automotive shredder residue by granulometric separation. MM Sci. J. 18101813. https://doi.org/10.17973/MMSJ.2017_06_2016153

Singh, J., Chang, Y.-Y., Yang, J.-K., Kang, S.-H., Koduru, J.R., 2016a. Utilization of nano/micro-size iron recovered from the fine fraction of automobile shredder residue for phenol degradation in water. Front. Environ. Sci. Eng. 10, 9. https://doi.org/10.1007/s11783 016-0848-8

Singh, J., Lee, B.K., 2016a. Kinetics and extraction of heavy metals resources from automobile shredder residue. Process Saf. Environ. Prot. 99, 69-79. https://doi.org/10.1016/j.psep.2015.10.010

Singh, J., Lee, B.K., 2016b. Recovery of precious metals from low-grade automobile shredder residue: A novel approach for the recovery of nanozero-valent copper particles. Waste Manag. 48, 353-365. https://doi.org/10.1016/j.wasman.2015.10.019

Singh, J Lee, B.K, 2015a. Hydrometallurgical recovery of heavy metals from low grade automobile shredder residue (ASR): An application of advanced Fenton process (AFP). J. Environ. Manage. 161, 1-10. https://doi.org/10.1016/j.jenvman.2015.06.034 
Singh, J., Lee, B.K., 2015b. Reduction of environmental availability and ecological risk of heavy metals in automobile shredder residues. Ecol. Eng. 81, 76-81. https://doi.org/10.1016/j.ecoleng.2015.04.036

Singh, J., Lee, B.K., 2015c. Pollution control and metal resource recovery for low grade automobile shredder residue: A mechanism, bioavailability and risk assessment. Waste Manag. 38, 271-283. https://doi.org/10.1016/j.wasman.2015.01.035

Singh, J., Lingamdinne, L.P., Yang, J.K., Chang, Y.Y., Lee, B.K., Koduru, J.R., 2017. Effect of $\mathrm{pH}$ values on recovery of nano particles (NPs) from the fine fraction of automobile shredder residue (ASR): An application of NPs for phenol removal from the water. Process Saf. Environ. Prot. 105, 51-59. https://doi.org/10.1016/j. psep.2016.10.011

Singh, J., Yang, J.K., Chang, Y.Y., 2016b. Synthesis of nano zero-valent metals from the leaching liquor of automobile shredder residue: A mechanism and potential applications for phenol degradation in water. Process Saf. Environ. Prot. 102, 204-213. https://doi. org/10.1016/j.psep.2016.03.013

Singh, J., Yang, J.K., Chang, Y.Y., 2016c. Quantitative analysis and reduction of the eco-toxicity risk of heavy metals for the fine fraction of automobile shredder residue (ASR) using $\mathrm{H} 2 \mathrm{O} 2$. Waste Manag. 48, 374-382. https://doi.org/10.1016/j.wasman.2015.09.030

Šyc, M., Krausová, A., Kameníková, P., Šomplák, R., Pavlas, M., Svoboda, K., Punc, M., Zach, B., Pohor, M., 2018. Material analysis of Bottom ash from waste-to-energy plants. Waste Manag. 73, 360-366. https://doi.org/10.1016/j.wasman.2017.10.045

Tang, J., Steenari, B.M., 2016. Leaching optimization of municipal solid waste incineration ash for resource recovery: A case study of $\mathrm{Cu}, \mathrm{Zn}, \mathrm{Pb}$ and $\mathrm{Cd}$. Waste Manag. 48, 315-322. https://doi. org/10.1016/j.wasman.2015.10.003
Tanigaki, N., Manako, K., Osada, M., 2012. Co-gasification of municipal solid waste and material recovery in a large-scale gasification and melting system. Waste Manag. 32, 667-675. https://doi. org/10.1016/j.wasman.2011.10.019

van Beers, D., Bossilkov, A., Lund, C., 2009. Development of large scale reuses of inorganic by-products in Australia: The case study of Kwinana, Western Australia. Resour. Conserv. Recycl. 53, 365378. https://doi.org/10.1016/j.resconrec.2009.02.006

van der Zwan, J.T., 1997. Application of waste materials a success now, a success in the future. Waste Mater. Constr. Putt. Theory into Pract. 869-881. https://doi.org/10.1016/S0166-1116(97)80272-5

Van Gerven, T., Geysen, D., Stoffels, L., Jaspers, M., Wauters, G., Vandecasteele, C., 2005. Management of incinerator residues in Flanders (Belgium) and in neighbouring countries. A comparison. Waste Manag. 25, 75-87. https://doi.org/10.1016/j.wasman.2004.09.002

Verbinnen, B., Billen, P., Van Caneghem, J., Vandecasteele, C., 2017. Recycling of MSWI Bottom Ash: A Review of Chemical Barriers, Engineering Applications and Treatment Technologies. Waste and Biomass Valorization 8, 1453-1466. https://doi.org/10.1007/ s12649-016-9704-0

Vermeulen, I., Van Caneghem, J., Block, C., Baeyens, J., Vandecasteele, C., 2011. Automotive shredder residue (ASR): Reviewing its production from end-of-life vehicles (ELVs) and its recycling, energy or chemicals' valorisation. J. Hazard. Mater. 190, 8-27. https://doi. org/10.1016/j.jhazmat.2011.02.088

Vorobieff, G., 2010. Challenges confronting sustainable practices for concrete pavement design and construction in Australia. Int. J. Pavement Res. Technol. 3, 259-269.

Zorpas, A.A., Inglezakis, V.J., 2012. Automotive industry challenges in meeting EU 2015 environmental standard. Technol. Soc. 34, 5583. https://doi.org/10.1016/j.techsoc.2011.12.006 